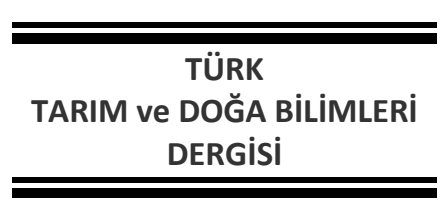

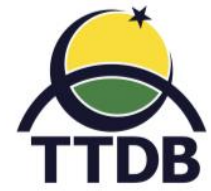

www.dergipark.gov.tr/turkjans

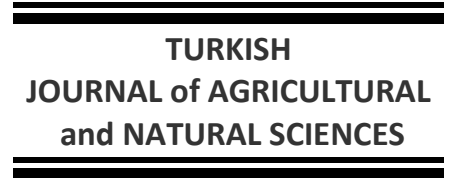

Araştırma Makalesi

\title{
Pazarlama Dışı Olan Karpuzlardan (Citrullus lanatus) Hayvan Beslemede Kullanılabilecek Yan Ürünlerin Elde Edilmesi, Depolanması, Bazı Besin Madde ve Mikrobiyolojik Özelliklerinin Belirlenmesi\&
}

\author{
Fatma TERLEMEZ ${ }^{1 *}$, ibrahim Halil ÇERÇi ${ }^{2}$ \\ ${ }^{1}$ Bingöl Üniversitesi, Veteriner Fakültesi, Zootekni ve Hayvan Besleme Bölümü, Bingöl \\ ${ }^{2}$ Hatay Mustafa Kemal Üniversitesi, Veteriner Fakültesi, Zootekni ve Hayvan Besleme Bölümü, Hatay \\ *Sorumlu Yazar: fterlemez@bingol.edu.tr
}

Geliş Tarihi: 05.07.2019

Düzeltme Geliş Tarihi: 29.08.2019

Kabul Tarihi: 10.09.2019

\section{Özet}

Çalışmada, pazar dışı kalma durumunda olan karpuzların kabuk, çekirdek ve etli kısımlarının tamamından katma değerli ve dayanıklı karpuz ürünlerini üretilmesi amaçlanmıştır. Araştırmada hasatı üzerinden 15 gün geçmiş karpuzlardan karpuz suyu, karpuz püresi ve karpuz posası olmak üzere üç farklı ürün üretilmiştir. Bu ürünlerin hiçbir muamele yapılmamış olana taze grup, buhar basınçlı ısıl işlem uygulanmış olana asitsiz grup ve buhar basınçıı ısıl işlem + sitrik asit ilavesi uygulanmış olana da asitli grup adı verilmiştir. Çalışmada taze örneklerde, konserve işlemlerinden hemen sonra alınan örneklerde, 0., 30., 90. ve 180. gün depolanan örneklerde kimyasal ve mikrobiyolojik analizler yapılmışır. Karpuzlardan elde edilen ürünler posa, püre ve su olarak tanımlanmıştır. Konserve işlemlerinden hemen sonra alınan örneklerin (asitli ve asitsiz) sonuçlarına göre her iki muamelede de mikrobiyolojik açıdan pastörizasyon sağlanmıştır. Depolamanın 0., 30., 90. ve 180. günlerinde açılan konserve ürünlerinden alınan örneklerde mikroorganizma üreme durumları incelenmiştir. Asitli gruba göre asitsiz grupta daha yüksek toplam mezofilik aerobik bakteri $(p<0.01)$ ve toplam Clostridia $(p<0.01)$ ürediği tespit edilmiştir. 0 . gün depolamaya göre; 30. ve 90. günlük depolamalarda her iki bakteri sayısı artmış ancak 180. günde alınan örneklerde ise bakteri sayıları azalmıştır. Çalışmada, pazarlama dışı kalmış karpuzlardan hayvan beslemede kullanılabilecek karpuz suyu, karpuz püresi ve karpuz posası üretilebileceği belirlenmiştir. Diğer uygulamalara göre, asit katkısı + ısıl işlem uygulamasının daha uygun olduğu görülmüştür.

Anahtar Kelimeler: Karpuz, ısıl işlem, sitrik asit.

\section{Obtaining the By-Products That Can Be Used in Animal Nutrition from Non-Marketing Watermelons, Storage of These Products, Researching Some Nutrient and Microbiological Properties}

\footnotetext{
Abstract

In the study, it was aimed to produce value-added and durable watermelon products from the rind, seeds and fleshy parts of the watermelons which are out of market. In the research, three different products were produced watermelon juice, watermelon puree and watermelon pulp from watermelons that were harvested 15 days ago. No treatment of these products was called fresh group, the steam pressurized heat treated group was called acid-free group and the steam pressurized heat treated + citric acid addition was called acidic group. In this study, chemical and microbiological analyzes were carried out on fresh samples, samples taken immediately after canning processes, samples stored at 0., 30., 90. and 180. days. The products obtained from watermelons are defined as pulp, puree and water. According to the results of the samples taken immediately after canning processes (with and without acid), pasteurization was provided microbiologically in both treatments. Microbiological reproduction status of the samples taken from the canned products opened on the 0., 30., 90 . and 180. days of storage were examined. It was determined that total mesophilic aerobic bacteria $(p<0.01)$ and total Clostridia $(p<0.01$ ) were higher in the acid-free group than the acidic group. According to storage on day
} 
0.; In the 30. and 90. day storage, both bacteria numbers increased but in the 180. day samples the number of bacteria decreased. In the study, it was determined that watermelon juice, watermelon puree and watermelon pulp which can be used in animal feeding can be produced from the non-marketing watermelons. It has been found that acid addition + heat treatment is more suitable than other applications.

Key words: Watermelon, heat treatment, citric acid.

\section{Giriş}

Karpuz (Citrullus lanatus) kabak veya kabakgillerden Cucurbitaceae ailesine ait olan bir bitkidir (Dane ve Liu, 2007). Karpuz dünyanın sıcak bölgelerinde yetiştirilmektedir (Sabahelkhier ve ark., 2011). Karpuz üretiminde Çin birinci sırada yer almakta ve ardından Türkiye, ABD, İran ile Kore Cumhuriyeti gelmektedir (Naz ve ark., 2013; Zohary ve Hopf, 2019).

Karpuzlar uzun süre depolanamaz (Bangera, 1997). Karpuzlar oda sıcaklıklarında yaklaşık 1 hafta; $7.5^{\circ} \mathrm{C}$ ile $10^{\circ} \mathrm{C}$ sıcaklıklarda ve $\% 80$ - \%90 bağıl nemde ise 2 ile 3 hafta süre saklanabilir (TSE, 2019). ABD'de pazarlanamadığı için tarlada kalan karpuz oranının yaklaşık \%20 düzeyinde olduğu vurgulanmaktadır (Fish ve ark., 2009). TUik (2019) verilerine göre Türkiye'de yıllık 4 milyon ton karpuz üretilmektedir. Bunun \%20 kadarı pazarlanamadığı kabul edildiğine (Fish ve ark., 2009) göre yaklaşık Türkiye'de 800 bin ton karpuz yok olmaktadır. Tüketiciler karpuzu daha çok taze olarak tüketmektedir. Bu nedenle karpuzun suyu, meyve nektarı ve meyve kokteylleri üretiminde kullanıımaya çalışılmıştır. Kabuk ve tohumları daha çok atık olarak değerlendirmiştir (Wani ve ark., 2006; 2011). Diğer bir çalışmada (Conto ve ark., 2011) da karpuz neredeyse sadece taze meyve olarak tüketildiği az da olsa meyve suları, jeller, reçel, soslar ve salatalarda da kullanıldığı, bazı ülkelerde kabuklarının turşusu yapıldığı, Çin, Asya ve Ortadoğu'nun çeşitli bölgelerinde tohumlarının tüketildiği, Hindistan'da karpuz çekirdeği unu ekmek yapımında kullanıldığı, Güney Rusya'da biranın bir katkı maddesi olarak karpuz suyundan üretildiği bildirilmektedir. Karpuz çekirdekleri Çin ve İsrail'de aperatif olarak kullanılmasının yanında karpuz suyu şarabın içinde de kullanılır. Sudan, Nijerya ve Mısır'da pulp pişirilmekte ve tohumlar yenmektedir (Johnson ve ark., 2013). Öte yandan, karpuzdan likopen ekstra edilerek katma değerli ürünlerin üretilmesi, Amerika Birleşik Devletleri'nde 34 milyon dolar değer sağlamıştır. Bu ürünler ise ya diyet takviyesi ya da doğal gıda renklendirici olarak kullanılabilmektedir (Collins ve ark., 2006).

Özellikle kaliteli kaba yem ve karma yem açığı olan ülkelerde bu bağlamda pazarlanamayan karpuzların dayanıklı ürünler haline getirilmesi düşüncesi çok büyük önem taşımaktadır (Karagöz, 2009). Karpuzun tarlada veya pazarda çürümeye bırakılmaması, ekonomiye kazandırılması için hayvan beslemede kullanılabilecek dayanıklı karpuz ürünlerini üretme olanaklarının araştırılmasının gerekliliğini göstermektedir. Karpuzun iyi bir organik ve inorganik besin konsantresi olması onun önemini daha da artırmaktadır (Colla ve ark., 2006; Johnson ve ark., 2013; Naz ve ark., 2013; TSE, 2019; USDA, 2019).

Mevsimsel üretim özelliğinde olan, olgunlaştıktan sonra pazarlanma süresinin iki haftayla sınırlı olmasından, çeşitli sebeplerden dolayı tarlada kalmasından ve bazı durumlarda da doğal olaylar veya bazı zararlıların etkisi ile karpuzlar pazarlanma özelliğini kaybetmektedir. Bundan yola çıkarak bu araştırmada, pazar dışı kalma durumunda olan ve bir ölçüde atık durumuna düşen karpuzların kabuk, çekirdek ve etli kısımlarının tamamından yararlanılacak biçimde işlenerek, en az besin madde kaybı ile yem sektörü ve hayvan beslemede, yiyecek ve içecek olarak kullanılma özelliklerini taşıyabilen katma değerli ve dayanıklı karpuz ürünlerinin üretilmesi amaçlanmıştır. Bu amaçla da çalışmada taze ve farklı depolama süresinde konserve edilmiş karpuz ürünlerinin bazı besin madde ve mikrobiyolojik düzeyleri araştırılmıştır.

\section{Materyal ve Yöntem}

Çalışmada kullanılan karpuzlar: Hasatından yaklaşık 15 gün sonra sofralık özelliğini veya pazarlanma şansını bir ölçüde kaybetmiş karpuzlar satış noktalarından alınmış ve 1 hafta içerisinde işlenmiştir.

Karpuz ürünlerin dayanıklı hale getirilmesinde uygulanan işlemler: Çalışmada buhar basınçlı ısıl işlem ve buhar basınçlı ısıl işlem + sitrik asit katkısı olmak üzere iki farklı işlem uygulanmıştır.

Karpuzlar fırçalı bir sistemle yıkanıp kurutulmuş ve karpuzlar kıyma makinasında çekilecek boyutlarda doğranmıştır. Karpuzun tüm kısımlarından daha etkin yararlanmak için doğranan karpuzlar kabuğu, eti ve çekirdeği ile birlikte kıyma makinasında iyice parçalanıp mayşe (püre) haline getirilmiştir. Daha sonra püre, katı meyve sıkacağından geçirilerek karpuz suyu ve karpuz posasına ayrılmıştır. Elde edilen karpuz püresi, karpuz suyu ve karpuz posası ürünleri dayanıklı hale getirilebilmek için; a. Ürünlerin bir grubu düdüklü tencerede buhar basınçlı (10 dakika, 0.85 bar basınç) ısıl işleme (asitsiz) tabi tutulmuştur. b. Ürünlerin bir grubu da buhar basınçlı ısıl işlem + 
sitrik asit (asitli) (pH 4'e düşünceye kadar \%99,7 saflıkta sitrik asit monohydrat ilavesi yapılmıştır) işlemine tabi tutulmuştur (Yaralı, 2019).

Araştırma, üretim ve depolama süreci olmak üzere iki aşamada tamamlanmıştır.

Üretim sürecinde karpuz ürünlerinin dayanıklı hale getirilmesi sırasında her üründe tazesine göre meydana gelen kimyasal ve mikrobiyolojik değişimler tespit edilmiştir. Karpuzlardan elde edilen ürünlere (püre, su ve posa) işlem görmemiş (taze), ısıl işlem görmüş (asitsiz) ve ısıl işlem + sitrik asit katkılı (asitli) olmak üzere üç farklı muamele uygulanmıştır. Her ürün ve muamele grubu altışar tekerrürden (1 kg'lık 6'şar cam kavanoz) oluşturulmuştur.

Depolama sürecinde konserve ürünlerin depolanması sırasında meydana gelen kimyasal ve mikrobiyolojik değişimler takip edilmiştir. Diğer bir deyişle karpuz ürünlerinin depolanma süreci araştırılmıştır (Gökmen ve Öztan, 1995). Bu çalışmada, cam konserve kavanozları oda sıcaklığında kapalı koliler içerisinde depolanmıştır. Karpuzlardan elde edilen ürünler (püre, su, posa) Isıl işlem görmüş (asitsiz) ve ısıl işlem + sitrik asit katkısı (asitli) yapılmış olarak iki muamele şeklinde ayrılmıştır. Asitli ve asitsiz karpuz ürünleri depolamada 0., 30., 90. ve 180. günler olmak üzere 4 zaman dilimine ayrılmıştır. Bu denemede de her ürün, her muamale ve depolama zaman diliminde altışar tekkerrür (Her gruptan 6 kavanoz) yapılmıştır.

Örnek Alımı: Her gruptan altı kavanoz açılarak steril kaplara örnekler alınarak Clostridia sayımları hemen yapılmıştır. Diğer kimyasal parametreler ve mikrobiyolojik ekimler için analiz edilinceye kadar örnekler $-20^{\circ} \mathrm{C}^{\prime}$ de saklanmıştır.

Ham Besin Maddeleri ve $\mathrm{pH}$ Analizi: Araştırmanın üretim ve depolama aşamasındaki her tekerrürden alınan örneklerde paralelli olarak Kuru madde kurutma dolabında, ham protein Kjeldahl cihazında, AOAC'de (1990) belirtilen yöntemlerle, pH'ları dijital $\mathrm{pH}$ metre ve Ham selüloz Fiber Analyzer Ankom 220'de (Van Soest ve ark., 1991) belirlenmiştir.

Toplam maya ve küf sayısının belirlenmesi: Toplam maya ve küf sayısı için yayma metoduyla, Dichloran Rose-Bengal Chloramphenicol Agar'a (DRBC) (Merck, Darmstadt/Germany) ekimler yapılarak $25^{\circ} \mathrm{C}^{\prime}$ de 5-7 gün inkübasyona bırakılmıştır. İnkübasyon süresinin sonunda gelişen tüm kolonilerde toplam maya ve küf sayımları yapılmıştır (FDA, 2001).

Toplam mezofilik aerob bakteri sayısının belirlenmesi: Toplam mezofilik aerob bakteri sayısı için plak dökme metoduyla, Plate Count Agar'a (PCA) (Merck, Darmstadt/Germany) ekimler yapılarak $35^{\circ} \mathrm{C}^{\prime}$ de $24-48$ saat inkübasyona bırakılmıştır. İnkübasyon süresinin sonunda gelişen tüm koloniler toplam mezofilik aerob bakteri olarak sayılmıştır (FDA, 2001).

Toplam clostridium spp. sayısının belirlenmesi: Toplam clostridium sayısı için plak dökme metoduyla, örnekler Reinforced Clostridial Agar'a (RCA) (Merck, Darmstadt/Germany) ekimler yapılarak anerobik jarlara yerleştirilip $35-37^{\circ} \mathrm{C}^{\prime}$ de 24-48 saat inkübasyona bırakılmıştır. İnkübasyon süresinin sonunda gelişen tüm koloniler toplam clostridium olarak sayılmıştır (Hirsch ve Grinsted, 1954).

Koliform bakteri sayısının belirlenmesi: Koliform bakteri sayısının tespiti için Violet Red Bile Agar'da (VRB) (Merck, Darmstadt/Germany) yayma metoduyla ekimler yapılarak $37^{\circ} \mathrm{C}^{\prime}$ de 24 saat inkübasyona bırakılmıştır. İnkübasyon süresi sonunda oluşan tüm koyu kırmızı renkli koloniler koliform bakteri olarak sayılmıştır (Anonim, 2006).

İstatistiksel analizler: Araştırmada elde edilen verilerin istatistiksel analizi IBM SPSS Statistics 22 programı yardımıyla çoklu grupların karşılaştırmasında faktöriyel deneme düzenine ait multifaktöriyel karşılaştırma yapılmıştır. Analizlerin yapılmasında General Linear Model (GLM) kullanılarak Varyans analizi ve Duncan testi uygulanmıştır. Araştırma sonuçlarına ait değerler ortalama \pm standart hata ortalaması olarak verilmiştir.

\section{Bulgular ve Tartışma}

Pazar dışı kalmış veya kalma durumunda olan karpuzlardan üretilmiş konserve ürünlerin dayanıklı hale getirilmesi sırasında uygulanan muamelelere göre ve her ürünün tazesine (konserve edilmemiş) göre meydana gelen kimyasal ve mikrobiyolojik değişimler tespit edilmiştir. Ham besin madde düzeyleri ile $\mathrm{pH}$ değerlerine ilişkin veriler ve sonuçların istatistiksel değerlendirmeleri Çizelge 1 , 2 ve 3'te, mikroorganizma sayımlarına ilişkin veriler ise Çizelge 4 ve 5 'te verilmiştir. Buna göre karpuz ürünleri arasındaki farklar besin madde düzeyleri $(p<0.0001)$ ve $\mathrm{pH}$ değerleri açısından istatistiksel olarak önemli olduğu saptanmıştır $(p<0.001)$. Muameleler arasındaki farklar kuru madde $(p<0.001)$ ve $\mathrm{pH} \quad(\mathrm{p}<0.0001)$ değerlerinde istatistiksel anlamda önemli; ham protein ve selüloz düzeyleri istatistiksel anlamda önemsiz bulunmuştur (Çizelge 1). Karpuz ürünleri açısından irdelendiğinde (Çizelge 2); en düşük kuru madde (\%6.64), ham protein (\%1.16) ve ham selüloz (\%0.27) düzeyleri karpuz suyunda ve $\mathrm{pH}$ (\%4.84) düzeyi karpuz posasında gözlemlenmiştir. Karpuz ürünleri açısından; En yüksek kuru madde (\%14.61), ham protein (\%1.89) ve ham selüloz (\%2.76) düzeyleri karpuz posasında ve $\mathrm{pH}(\% 5.02)$ düzeyi karpuz suyunda tespit edilmiştir (Çizelge 2). Bu da 
karpuzun sulu kısmının karpuz suyunda, kabuk çekirdekler başta olmak üzere katı kısımlarının karpuz püresi daha fazla da karpuz posasında toplanmasından kaynaklanabilir. Nitekim, olgunlaşmış ve olgunlaşmamış karpuzların karşılaştırıldığı bir çalışmada (Sa'id, 2014) olgunlaşmış karpuzda nem \%91.5, karbonhidrat \%6.5, olgunlaşmamışta ise nem \%94.8, karbonhidrat \%3.5, biçiminde bir farklılık tespit edilmiştir. Diğer bir deyişle, karpuzda olgunlaşma ile kuru madde ve organik madde içeriği artış göstermiştir. Karpuzun kabuğunun (Erukainure ve ark., 2010) etli kısmı (USDA, 2019) ile karşılaştırılmasında sırası ile nem oranın \%91.22 ve $\% 91.45$, ham yağ $\% 0.69$ ve $\% 0.15$, ham protein $\% 1.52$ ve $\% 0.61$ ve ham selüloz $\% 0.97$ ve $\% 0.4$ biçiminde olduğu gözlenmektedir. Karpuzun kuru tohumunun $100 \mathrm{~g}$ başına ortalama $32 \mathrm{gr}$ protein ve 51.4 gr yağ ihtiva ettiği bildirilmiştir. Total ham lif (fiber) $47.7 \mathrm{~g}$ ve nem \%50.7 olarak tespit edilmiştir (Kamel ve ark., 1985) Diğer bir çalışmada (Acar ve ark., 2012) karpuz çekirdeğinin \%16.06-18.13 ham protein, \%23.31-26.83 ham yağ ve \%44.70-45.72 ham selüloza sahip olduğu belirtilmiştir.

Çizelge 1. Taze ve konserve karpuz ürünlerinin ham besin madde (\%yaş madde) ve $\mathrm{pH}$ değerleri ( $n=6)$

\begin{tabular}{|c|c|c|c|c|c|}
\hline Ürün & Muamele & Kuru madde & Ham protein & Ham selüloz & $\mathrm{pH}$ \\
\hline & Taze & 6.38 & 1.01 & 0.25 & 5.39 \\
\hline \multirow[t]{2}{*}{ Su } & Asitli & 6.74 & 1.21 & 0.28 & 4.12 \\
\hline & Asitsiz & 6.79 & 1.27 & 0.28 & 5.54 \\
\hline \multirow{3}{*}{ Püre } & Taze & 8.88 & 1.16 & 0.54 & 5.41 \\
\hline & Asitli & 9.70 & 1.24 & 0.57 & 4.07 \\
\hline & Asitsiz & 8.76 & 1.21 & 0.68 & 5.40 \\
\hline \multirow{3}{*}{ Posa } & Taze & 14.44 & 1.93 & 2.69 & 5.41 \\
\hline & Asitli & 15.48 & 1.87 & 2.96 & 4.17 \\
\hline & Asitsiz & 13.91 & 1.86 & 2.64 & 4.94 \\
\hline \multirow{2}{*}{\multicolumn{2}{|c|}{ SEM $^{*}$}} & 0.225 & 0.093 & 0.057 & 0.045 \\
\hline & & \multicolumn{4}{|c|}{ p değeri } \\
\hline \multicolumn{2}{|c|}{ Ürün (Ü) } & 0.0001 & 0.0001 & 0.0001 & 0.001 \\
\hline \multicolumn{2}{|c|}{ Muamele (M) } & 0.001 & 0.545 & 0.153 & 0.0001 \\
\hline \multicolumn{2}{|l|}{ ÜxM } & 0.061 & 0.523 & 0.051 & 0.0001 \\
\hline
\end{tabular}

$\mathrm{p}<0.05$ istatistiksel açıdan önemlidir. *SEM: Standart hatanın ortalaması.

Çizelge 2. Karpuz ürünlerinin ortalama ham besin madde içerikleri (\%yaş madde) ve pH değeri

\begin{tabular}{lccccc}
\hline Ürünler & $\mathbf{n}$ & Kuru madde & Ham Protein & Ham Selüloz & $\mathbf{p H}$ \\
\hline Su & 18 & $6.64 \pm 0.10^{\mathrm{c}}$ & $1.16 \pm 0.06^{\mathrm{b}}$ & $0.27 \pm 0.01^{\mathrm{c}}$ & $5.02 \pm 0.16^{\mathrm{a}}$ \\
Püre & 18 & $9.11 \pm 0.18^{\mathrm{b}}$ & $1.20 \pm 0.04^{\mathrm{b}}$ & $0.59 \pm 0.03^{\mathrm{b}}$ & $4.96 \pm 0.15^{\mathrm{a}}$ \\
Posa & 18 & $14.61 \pm 0.23^{\mathrm{a}}$ & $1.89 \pm 0.06^{\mathrm{a}}$ & $2.76 \pm 0.07^{\mathrm{a}}$ & $4.84 \pm 0.13^{\mathrm{b}}$ \\
\hline
\end{tabular}

(a-c): Aynı sütunda farklı harfleri taşıyan değerler arasındaki fark önemlidir ( $p<0.05)$.

Veriler ortalama \pm standart hata olarak sunulmuştur.

Çizelge 3. Karpuz muamelelerinin ortalama ham besin madde içerikleri (\%yaş madde) ve pH değeri

\begin{tabular}{cccc}
\hline Muameleler & $\mathbf{n}$ & Kuru madde & $\mathbf{p H}$ \\
\hline Taze & 18 & $9.90 \pm 0.82^{\mathrm{b}}$ & $5.40 \pm 0.01^{\mathrm{a}}$ \\
Asitli & 18 & $10.64 \pm 0.89^{\mathrm{a}}$ & $4.12 \pm 0.02^{\mathrm{c}}$ \\
Asitsiz & 18 & $9.82 \pm 0.75^{\mathrm{b}}$ & $5.29 \pm 0.08^{\mathrm{b}}$ \\
\hline
\end{tabular}

(a-c): Aynı sütunda farklı harfleri taşıyan değerler arasındaki fark önemlidir $(p<0.05)$.

Veriler ortalama \pm standart hata olarak sunulmuştur.

Muamele gruplarının ortalama ham besin madde içerikleri ve $\mathrm{pH}$ değeri bulgularına göre; en düşük kuru madde (\%9.82) asitsiz grupta ve $\mathrm{pH}$ (\%4.12) asitli grupta tespit edilirken; en yüksek kuru madde (\%10.64) asitli grupta ve $\mathrm{pH}(\% 5.40)$ taze grupta gözlenmiştir (Çizelge 3 ). Bu sonuçların gerçekleşmesinde meyvelerin konserve edilmesinde ısıl işleme bağı olarak düşük $\mathrm{pH}$ değerinin önemli rol oynadığı düşünülmüştür (Artık, 1988).

Dayanıklı konserve ürünlerinde önemli olan, ürüne uygulanan ısıl işlem sonunda ürünlerdeki mikroorganizmaların yok edilip edilmemesidir. Bundan yola çıkarak araştırma kapsamında sofralık özelliğini kaybetmiş karpuzların, püre, su ve posa haline getirilmiş formlarına ısıl işlem ve asit + ısıl işlemler uygulanarak taze ürünleri ile 
karşılaştırılmıştır. Bu kapsamda her karpuz çeşidinde toplam aerobik mezofilik bakteri, toplam maya, küf, koliform ve Clostridia üremelerine bakılmıştır. Tazesine göre gerek ısıl işlem gerekse sitrik asit katkısı + ısıl işlem uygulanmasına bağı olarak püre, posa ve su formundaki karpuz konservelerinin ortalama mikroorganizma içerikleri arasındaki farklılıklar istatistiksel anlamda önemli bulunmuştur (Çizelge 4). Bu sonuç, daha önceden yapılmış çalışmalardan (Acar, 1978; Hayoğlu ve Fenercioğlu, 1990) elde edilen sonuçlar ile benzerlik göstermiştir. Toplam mezofilik aerobik bakteri, toplam maya, toplam küf, toplam koliform ve toplam Clostridia sayısı bakımından karpuzdaki muameleler (taze, asitli ve asitsiz) arasında farklılık önemli bulunmuştur (Çizelge 5).
Asitli ve asitsiz ısıl işlem grupları arasında ise istatistiksel bir fark olmamıştır (Çizelge 5). Gıdaların dayanıklı hale getirilmesinde bozulmaya neden olan mikroorganizmaları tahrip etmek veya gelişmesini önlemek için ısıl işlemler uygulanıp (Mann ve ark., 2001; Lambert, 2003; Zanoni ve ark., 2003), doğal veya kimyasal koruyucular kullanılmaktadır (Aran, 1986). Gıdalardaki mikrobiyolojik bozulmaların en önemli nedeni yeterli ısıl işlem uygulanmaması ve sızıntı sonrası meydana gelen kontaminasyonlardır (Acar, 1982). Çizelge 4 ve 5 incelendiğinde; tazesine göre karşılaştırıldığında konserve işlemlerinden hemen sonra alınan örneklerin (asitli ve asitsiz) sonuçlarına göre her iki muamelede de mikrobiyolojik açıdan pastörizasyon sağlandığı gözlenmektedir.

Çizelge 4. Taze ve konserve karpuz ürünlerinin ortalama mikroorganizma sayıları $\left(\log _{10} \mathrm{kob} / \mathrm{g}\right)(\mathrm{n}=6)$

\begin{tabular}{|c|c|c|c|c|c|c|}
\hline Ürün & Muamele & $\begin{array}{c}\text { Toplam mezofilik } \\
\text { aerobik }\end{array}$ & $\begin{array}{c}\text { Toplam } \\
\text { maya }\end{array}$ & $\begin{array}{l}\text { Toplam } \\
\text { Küf }\end{array}$ & $\begin{array}{l}\text { Toplam } \\
\text { Koliform }\end{array}$ & $\begin{array}{c}\text { Toplam } \\
\text { Clostridia }\end{array}$ \\
\hline \multirow{3}{*}{ Su } & Taze & 3.82 & 1.56 & 1.90 & 1.75 & 4.60 \\
\hline & Asitli & $<1$ & $<1$ & $<1$ & $<1$ & $<1$ \\
\hline & Asitsiz & $<1$ & $<1$ & $<1$ & $<1$ & $<1$ \\
\hline \multirow{3}{*}{ Püre } & Taze & 4.06 & 1.37 & 1.73 & 2.55 & 4.86 \\
\hline & Asitli & $<1$ & $<1$ & $<1$ & $<1$ & $<1$ \\
\hline & Asitsiz & $<1$ & $<1$ & $<1$ & $<1$ & 1.09 \\
\hline \multirow{3}{*}{ Posa } & Taze & 2.94 & 1.36 & 1.57 & 1.84 & 4.63 \\
\hline & Asitli & $<1$ & $<1$ & $<1$ & $<1$ & $<1$ \\
\hline & Asitsiz & $<1$ & $<1$ & $<1$ & $<1$ & $<1$ \\
\hline \multirow{2}{*}{\multicolumn{2}{|c|}{ SEM* }} & 0.124 & 0.102 & 0.124 & 0.154 & 0.059 \\
\hline & & & & değeri & & \\
\hline \multicolumn{2}{|c|}{ Ürün (Ü) } & 0.114 & 0.879 & 0.823 & 0.413 & 0.144 \\
\hline \multicolumn{2}{|c|}{ Muamele (M) } & 0.0001 & 0.002 & 0.0001 & 0.0001 & 0.0001 \\
\hline \multicolumn{2}{|c|}{ ÜxM } & 0.075 & 0.971 & 0.940 & 0.471 & 0.643 \\
\hline
\end{tabular}

p<0.05 istatistiksel açıdan önemlidir. *SEM: Standart hatanın ortalaması.

Çizelge 5. Karpuz muamelelerinin ortalama mikroorganizma sayıları $\left(\log _{10} \mathrm{kob} / \mathrm{g}\right)$

\begin{tabular}{ccccccc}
\hline Muameleler & $\mathbf{n}$ & $\begin{array}{c}\text { Toplam mezofilik } \\
\text { aerobik }\end{array}$ & $\begin{array}{c}\text { Toplam } \\
\text { maya }\end{array}$ & $\begin{array}{c}\text { Toplam } \\
\text { küf }\end{array}$ & $\begin{array}{c}\text { Toplam } \\
\text { Koliform }\end{array}$ & $\begin{array}{c}\text { Toplam } \\
\text { Clostridia }\end{array}$ \\
\hline Taze & 18 & $3.61 \pm 0.24^{\mathrm{a}}$ & $1.43 \pm 0.17^{\mathrm{a}}$ & $1.73 \pm 0.21^{\mathrm{a}}$ & $2.05 \pm 0.27^{\mathrm{a}}$ & $4.70 \pm 0.08^{\mathrm{a}}$ \\
Asitli & 18 & $0.95 \pm 0.01^{\mathrm{b}}$ & $0.95 \pm 0.01^{\mathrm{b}}$ & $0.95 \pm 0.01^{\mathrm{b}}$ & $0.95 \pm 0.01^{\mathrm{b}}$ & $0.95 \pm 0.01^{\mathrm{b}}$ \\
Asitsiz & 18 & $0.95 \pm 0.01^{\mathrm{b}}$ & $0.95 \pm 0.01^{\mathrm{b}}$ & $0.95 \pm 0.01^{\mathrm{b}}$ & $0.95 \pm 0.01^{\mathrm{b}}$ & $1.00 \pm 0.05^{\mathrm{b}}$ \\
\hline
\end{tabular}

(a-b): Aynı sütunda farklı harfleri taşıyan değerler arasındaki fark önemlidir ( $p<0.05)$.

Veriler ortalama \pm standart hata olarak sunulmuştur.

Konserve karpuz ürünlerinin farklı depolama sürelerinde ham besin madde düzeyleri ve $\mathrm{pH}$ değerlerine ilişkin veriler Çizelge 6, 7, 8 ve 9'da sunulmuştur. Konserve karpuz ürünlerinde farklı depolama sürelerinde mikroorganizma sayımlarına ilişkin sonuçlar ise Çizelge 10,11 ve $12^{\prime} \mathrm{de}$ verilmiştir.

Dayanıksız bitkisel ürünlerin uygulamaya aktarılmasında sadece bitkisel ürünlerin dayanıklı ürünlere dönüştürülmesi yeterli olmamaktadır. Bu konserve ürünlerin depolamaya ne kadar uygun olduğunun da tespit edilmesi çok önemlidir. Bundan dolayı bu araştırmada ışıksız ve hava akımına açık bir yerde depolanmasında besin maddelerindeki değişimler tespit edilmiştir (Çizelge 6, 7, 8, 9). Ayrıca ürünlerde mikrobiyel düzeydeki değişimler de tespit edilmiştir (Çizelge 10, 11, 12). Depolama sürecinde konserve karpuz ürünlerinin ortalama ham besin madde içerikleri ürünler açısından değerlendirildiğinde en düşük besin madde düzeyleri karpuz suyunda en yüksek besin madde değerleri karpuz posasında bulunmaktadır. 
Konserve karpuz ürünlerinde bulunan ham besin madde düzeyleri (kuru madde, ham protein ve ham selüloz) yüksekten düşüğe doğru posa, püre ve su biçiminde sıralanmıştır (Çizelge 7). 0. güne göre depolama süresindeki artışa bağı olarak karpuz ürünlerinin kuru madde, ham protein ve ham selüloz değerlerinde bir azalma meydana gelmiştir (Çizelge 8). Asitli ve asitsiz konserve karpuz ürünlerinin ortalama ham besin madde değerleri incelendiğinde; asitli muamele grubunun kuru madde ve ham protein değerlerinin daha yüksek olduğu tespit edilmiştir (Çizelge 9).

Çizelge 6. Konserve karpuz ürünlerinde farklı depolama sürelerinde ham besin madde (\%yaş madde) ve $\mathrm{pH}$ değerleri $(n=6)$

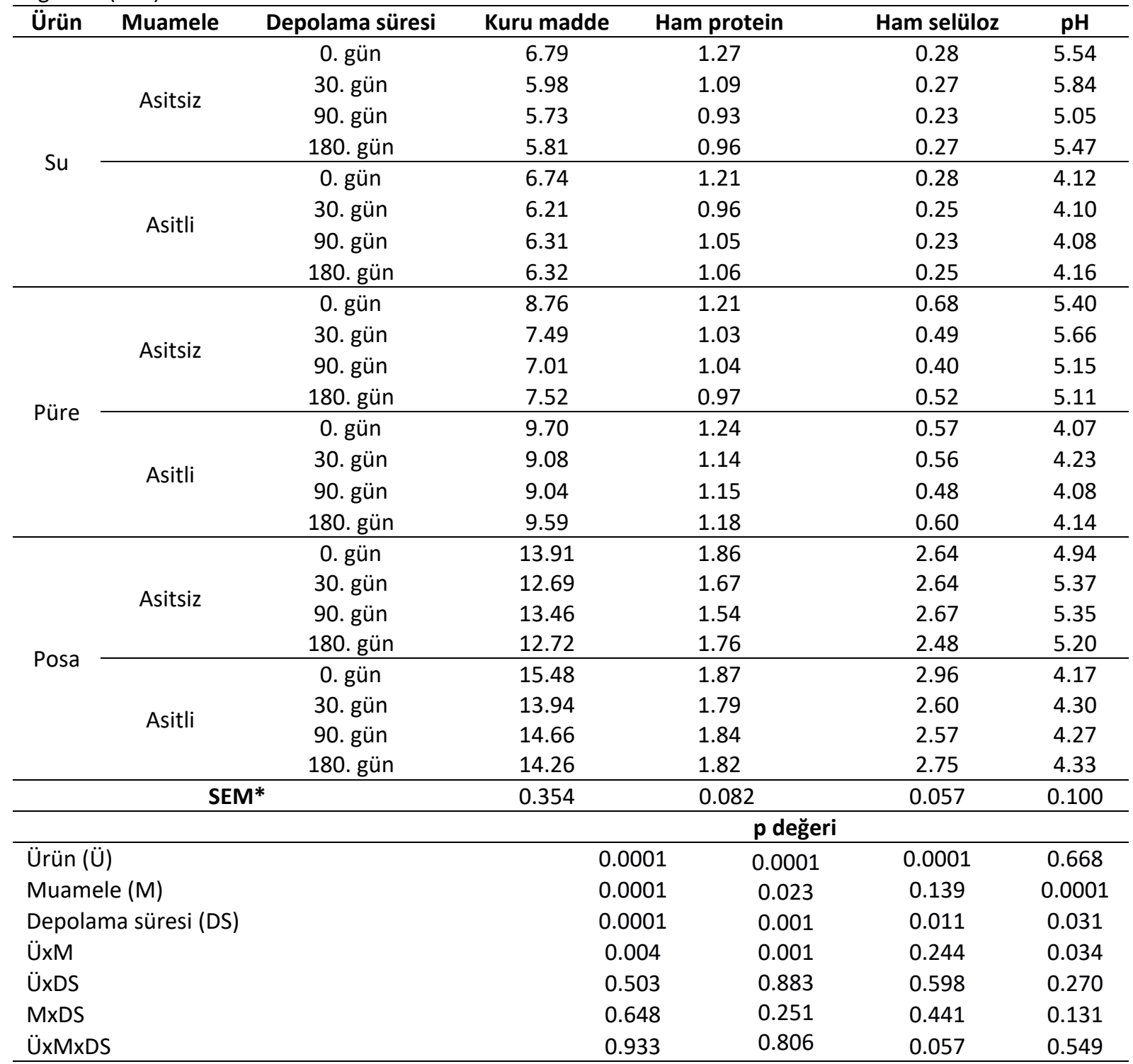

p<0.05 istatistiksel açıdan önemlidir. *SEM: Standart hatanın ortalaması.

Çizelge 7. Depolama sürecinde konserve karpuz ürünlerinin ortalama ham besin madde içerikleri (\%yaş madde)

\begin{tabular}{lcccc}
\hline Ürünler & $\mathbf{n}$ & Kuru madde & Ham Protein & Ham Selüloz \\
\hline Su & 48 & $6.24 \pm 0.09^{\mathrm{c}}$ & $1.07 \pm 0.03^{\mathrm{b}}$ & $0.26 \pm 0.01^{\mathrm{c}}$ \\
Püre & 48 & $8.52 \pm 0.21^{\mathrm{b}}$ & $1.12 \pm 0.03^{\mathrm{b}}$ & $0.54 \pm 0.02^{\mathrm{b}}$ \\
Posa & 48 & $13.89 \pm 0.20^{\mathrm{a}}$ & $1.77 \pm 0.03^{\mathrm{a}}$ & $2.67 \pm 0.04^{\mathrm{a}}$
\end{tabular}

(a-c): Aynı sütunda farklı harfleri taşıyan değerler arasındaki fark önemlidir $(p<0.05)$.

Veriler ortalama \pm standart hata olarak sunulmuştur. 
Çizelge 8. Farklı depolama süresinde konserve karpuz ürünlerinin ortalama ham besin madde (\%yaş madde) ve pH değerleri

\begin{tabular}{cccccc}
\hline Depolama süresi & $\mathbf{n}$ & Kuru madde & Ham Protein & Ham Selüloz & $\mathbf{p H}$ \\
\hline 0. gün & 36 & $10.23 \pm 0.58^{\mathrm{a}}$ & $1.44 \pm 0.06^{\mathrm{a}}$ & $1.24 \pm 0.19^{\mathrm{a}}$ & $4.70 \pm 0.11^{\mathrm{b}}$ \\
30. gün & 36 & $9.23 \pm 0.55^{\mathrm{b}}$ & $1.28 \pm 0.06^{\mathrm{b}}$ & $1.14 \pm 0.18^{\mathrm{b}}$ & $4.91 \pm 0.15^{\mathrm{a}}$ \\
90. gün & 36 & $9.37 \pm 0.61^{\mathrm{b}}$ & $1.26 \pm 0.06^{\mathrm{b}}$ & $1.10 \pm 0.18^{\mathrm{b}}$ & $4.66 \pm 0.11^{\mathrm{b}}$ \\
180.gün & 36 & $9.37 \pm 0.56^{\mathrm{b}}$ & $1.30 \pm 0.07^{\mathrm{b}}$ & $1.14 \pm 0.18^{\mathrm{b}}$ & $4.73 \pm 0.09^{\mathrm{b}}$ \\
\hline
\end{tabular}

(a-c): Aynı sütunda farklı harfleri taşıyan değerler arasındaki fark önemlidir $(p<0.05)$.

Veriler ortalama \pm standart hata olarak sunulmuştur.

Çizelge 9. Asitli ve asitsiz konserve karpuz ürünlerinin ortalama ham besin madde düzeyleri (\%yaş madde)

\begin{tabular}{cccc}
\hline Besin maddeleri & $\mathbf{n}$ & Asitsiz & Asitli \\
\hline Kurumadde & 72 & $8.99 \pm 0.39$ & $10.11 \pm 0.41$ \\
Ham protein & 72 & $1.28 \pm 0.05$ & $1.36 \pm 0.05$ \\
pH & 72 & $5.34 \pm 0.07$ & $4.17 \pm 0.02$ \\
\hline
\end{tabular}

Veriler ortalama \pm standart hata olarak sunulmuştur.

Çizelge 10. Konserve karpuz ürünlerinde farklı depolama sürelerinde mikroorganizma sayıları $\left(\log _{10}\right.$ kob/g) $(n=6)$

\begin{tabular}{|c|c|c|c|c|}
\hline Ürün & Muamele & Depolama süresi & Toplam mezofilik aerobik & Toplam Clostridia \\
\hline \multirow{8}{*}{ Su } & \multirow{4}{*}{ Asitsiz } & 0. gün & $<1$ & $<1$ \\
\hline & & 30. gün & 3.47 & 1.71 \\
\hline & & 90. gün & 3.85 & 1.19 \\
\hline & & 180. gün & 2.87 & 1.93 \\
\hline & \multirow{4}{*}{ Asitli } & 0. gün & $<1$ & $<1$ \\
\hline & & 30. gün & $<1$ & $<1$ \\
\hline & & 90. gün & $<1$ & $<1$ \\
\hline & & 180. gün & $<1$ & $<1$ \\
\hline \multirow{8}{*}{ Püre } & \multirow{4}{*}{ Asitsiz } & 0. gün & $<1$ & 1.09 \\
\hline & & 30. gün & 5.40 & 2.48 \\
\hline & & 90. gün & 5.51 & 2.92 \\
\hline & & 180. gün & 3.05 & 1.57 \\
\hline & \multirow{4}{*}{ Asitli } & 0. gün & $<1$ & $<1$ \\
\hline & & 30. gün & 1.58 & 1.42 \\
\hline & & 90. gün & 1.02 & $<1$ \\
\hline & & 180. gün & 1.45 & $<1$ \\
\hline \multirow{8}{*}{ Posa } & \multirow{4}{*}{ Asitsiz } & 0. gün & $<1$ & $<1$ \\
\hline & & 30. gün & 4.08 & $<1$ \\
\hline & & 90. gün & 3.58 & 2.52 \\
\hline & & 180. gün & 2.14 & $<1$ \\
\hline & \multirow{4}{*}{ Asitli } & 0. gün & $<1$ & $<1$ \\
\hline & & 30. gün & 1.74 & $<1$ \\
\hline & & 90. gün & 2.58 & 2.52 \\
\hline & & 180. gün & 1.22 & $<1$ \\
\hline \multicolumn{3}{|c|}{ SEM* } & 0.481 & 0.276 \\
\hline & & & \multicolumn{2}{|c|}{ p değeri } \\
\hline \multicolumn{3}{|c|}{ Ürün (Ü) } & 0.178 & 0.349 \\
\hline \multicolumn{3}{|c|}{ Muamele (M) } & 0.0001 & 0.015 \\
\hline \multicolumn{3}{|c|}{ Depolama süresi (DS) } & 0.0001 & 0.016 \\
\hline \multicolumn{3}{|l|}{ ÜxM } & 0.109 & 0.140 \\
\hline \multicolumn{3}{|l|}{ ÜxDS } & 0.827 & 0.052 \\
\hline \multicolumn{3}{|l|}{ MxDS } & 0.001 & 0.613 \\
\hline \multicolumn{3}{|c|}{ ÜxMxDS } & 0.618 & 0.734 \\
\hline
\end{tabular}

$\mathrm{p}<0.05$ istatistiksel açıdan önemlidir. *SEM: Standart hatanın ortalaması.

Karpuz yüksek nem içeriğine sahip olmasından dolayı mikrobik bozulmaya oldukça duyarlı olup çevre sorunlarına yol açabilir (Oberoi ve Sogi, 2015). Ancak bu araştırmada 
mikroorganizmaların üremesi açısından etkin bir ısıl işlem ve asit katkısı uygulanarak dayanıklı karpuz suyu, posası ve püresi üretilmek suretiyle mikrobiyolojik bozulma minimize edilmeye çalışılmıştır. Elde edilen bu ürünler 0. 30., 90. ve 180. günlerde açılarak incelendiğinde (Çizelge 10) maya, küf ve koliform bakterilerin üremediği ancak toplam mezofilik aerobik ve clostridia'nın ürediği görülmüştür. Depolamanın 90. gününde toplam mezofilik aerobik ve clostridia üremelerinin en yüksek olduğu tespit edilmiş bunu 30. ve 180. günler takip etmiştir. Benzer sonuçlar daha önce karpuz sularında yapılmış çalışmada (Eke Ejiofor, 2016) tespit edilmiştir. Depolama sürecinde farklı sonuçların görülmesi ise mevcut mikroorganizma türlerinden kaynaklanabilmektedir. Ayrıca asitsiz karpuz ürünlerinde asitliye göre daha fazla toplam mezofilik aerobik ve clostridia üremesi tespit edilmiştir (Çizelge 11 ve 12). pH düzeyi bu çalışmanın asitsiz grubundakine benzer olan bir çalışmada (ljah ve ark., 2015) konserve karpuz suyunda depolama süresinin artışına bağlı olarak toplam mezofilik aerobik üremesinin arttığı tespit edilmiştir. Ancak, bu çalışmada mikrobiyolojik üreme açısından asit+ısıl işlem uygulanmış yöntem bir adım öne çıkmaktadır.

Çizelge 11. Farklı depolama sürelerinde konserve karpuz ürünlerinin ortalama mikroorganizma sayıları $\left(\log _{10}\right.$ $\mathrm{kob} / \mathrm{g})$

\begin{tabular}{cccc}
\hline Depolama süresi & $\mathbf{n}$ & Toplam mezofilik aerobik & Toplam Clostridia \\
\hline 0. gün & 36 & $0.95 \pm 0.00^{\mathrm{c}}$ & $0.97 \pm 0.02^{\mathrm{b}}$ \\
30. gün & 36 & $2.87 \pm 0.38^{\mathrm{a}}$ & $1.41 \pm 0.21^{\mathrm{ab}}$ \\
90. gün & 36 & $2.91 \pm 0.41^{\mathrm{a}}$ & $1.84 \pm 0.28^{\mathrm{a}}$ \\
180. gün & 36 & $1.95 \pm 0.32^{\mathrm{b}}$ & $1.22 \pm 0.19^{\mathrm{b}}$ \\
\hline
\end{tabular}

(a-c): Aynı sütunda farklı harfleri taşıyan değerler arasındaki fark önemlidir $(p<0.05)$.

Veriler ortalama \pm standart hata olarak sunulmuştur.

Çizelge 12. Asitli ve asitsiz konserve karpuz ürünlerinde toplam mezofilik aerobik bakteri ile Clostridia sayıları $\left(\log _{10} \mathrm{kob} / \mathrm{g}\right)$

\begin{tabular}{cccc}
\hline & $\mathbf{n}$ & Asitsiz & Asitli \\
\hline Toplam mezofilik aerobik & 72 & $3.07 \pm 0.29$ & $1.27 \pm 0.12$ \\
Toplam Clostridia & 72 & $1.60 \pm 0.18$ & $1.12 \pm 0.10$ \\
\hline
\end{tabular}

Veriler ortalama \pm standart hata olarak sunulmuştur.

\section{Sonuçlar ve Öneriler}

Konserve karpuz ürünleri sadece ısıl işlemle konserve yapılana göre, asit + ısıl işlem ile konserve yapılmasının daha iyi olduğu tespit edilmiştir. Konserve karpuz ürün çeşitlerinde ise üretim aşamasında püre üretiminde iş akışı daha kısa olmakta ve kuru madde ve besin madde yoğunluğu bakımından su ve posanın ortasında yer almaktadır. Karpuz suyu da başta süt emen hayvanlara süt ikame yemleri ve süte katılarak verilecekse veya tüm hayvan türlerine içecek olarak verilecekse, bazı katkı maddeleri hayvanlara sıvı içeceklerle birlikte verilecekse tercih edilebilir. Su tercih edildiği zaman posada üretilecektir. Daha iyi pres cihazları kullanılarak posadaki karpuz suyunu minimuma indirmek suretiyle elde edilen karpuz posası silaj katkı maddesi olarak değerlendirilebilir. Çalışmada elde edilen ürünlerde doğrulama analizleri ile birlikte bir yem ya da yem katkı maddesi olarak hayvan beslemede kullanılabilirliğinin belirlenmesi için çeşitli araştırmaların yapılmasına ihtiyaç duyulmaktadır.

\footnotetext{
Teşekkür

\& Bu çalışma TÜBiTAK tarafından 2140722

proje numarası ile desteklenmiştir. Bu makale
}

“Pazarlanma Şansı Azalan Karpuzlardan Hayvan Beslemede Kullanılabilecek Dayanıklı ve Katma Değerli Ürünler Üretme Olanaklarının Araştırılması" adlı doktora tezinden üretilmiştir.

\section{Kaynaklar}

Acar, J. 1978. Meyve Konservelerinde ve sularında bozulmalara neden olan küf mantarları. Gıda, 3(1): 23-26.

Acar, J. 1982. Kutu konservelerinde mikrobiyolojik kalite kontrolü. Gıda, 7(3): 139-144.

Acar, R., Özcan, M.M., Kanbur, G., Dursun N. 2012. Some physico-chemical properties of edible and forage watermelon seeds. Iranian Journal of Chemistry and Chemical Engineering, 31(4): 41-47.

Anonim, 2006. International Standard (ISO) 4832:2006 (E). Microbiology of food and animal feeding stuffs-Horizontal method for the enumeration on coliforms-Colonycount technique.

AOAC, 1990. Association of Official Analytical Chemists. Official Method of Analysis. 15th.ed. Washington, DC. USA. 
Aran, N. 1986. Konserve gıdaların mikrobiyolojik kontrolleri üzerinde bir derleme. Gıda, 11(2): 75-77.

Artık, N. 1988. Isıl işlemin meyvelerde neden olduğu değişiklikler. Gıda, 13(4): 245-252.

Bangera, H.J. 1997. Investigation of a Watermelon Pulp Fruit and Juice Extraction Device. Master, Mumbai, India: Bachelor of Engineering Mumbai University.

Colla, G., Roupahel, Y., Cardarelli, M. 2006. Effect of salinity on yield, fruit quality, leaf gas exchange and mineral composition of grafted watermelon plants. Hortic. Sci., 41: 622-627.

Collins, J.K., Perkins-Veazie, P., Roberts, W. 2006. Lycopene: from plants to humans. Hortscience, 41(5): 1135-1144.

Conto, L.C., Gragnani, M.A.L., Maus, D., Ambiel, H.C.I., Chiu, M.C., Grimaldi, R., Gonçalves, L.A.G. 2011. Characterization of crude watermelon seed oil by two different extractions methods. J. Am. Oil Chem. Soc., 88: 1709-1714.

Dane, F., Liu, J. 2007. Diversity and origin of cultivated and citron type watermelon (Citrtullus lanatus). Genet Resource Crop Evolution, 54: 1255-1265.

Eke Ejiofor, J. 2016. Microbial population and shelf life study of spiced water melon juice. European Journal of Food Science and Technology, 4(4): 1-11.

Erukainure, O.L., Oke, O.V., Daramola, A.O., Adenekan, S.O., Umanhonlen, E.E. 2010. Improvement of the biochemical properties of watermelon rinds subjected to saccharomyces cerevisiae solid media fermentation. Pakistan Journal of Nutrition, 9(8): 806-809.

FDA, 2001. Bacteriological Analytical Manual. Edition 8, January 2001.

Fish, W.W., Bruton, B.D., Russo, V.M. 2009. Watermelon juice: a promising feedstock supplement, diluent, and nitrogen supplement for ethanol biofuel production. Biotechnology for Biofuels, 2: 18.

Gökmen, V., Öztan, A. 1995. Gıdaların raf ömrünü etkileyen faktörler ve raf ömrünün belirlenmesi. Gıda, 20(5): 265-271.

Hayoğlu, i.A., Fenercioğlu, H. 1990. A research on the possibility of using watermelon in the fruit juice industry. Gıda, 15(6): 329-332.

Hirsch, A., Grinsted, E. 1954. Methods for the growth and enumeration of anaerobic spore formers from cheese, with observations on the effect of nişin. Journal of Dairy Research, 21(1): 101-110.
Ijah, U.J.J., Ayodele, H.S., Aransiola, S.A. 2015. Microbiological and some sensory attributes of water melon juice and watermelon-orange juice mix. Journal of Food Resource Science, 4(3): 49-61.

Johnson, J.T., Lennox, J.A., Ujong, U.P., Odey, M.O., Fila, W.O., Edem, P.N., Dasofunjo, K. 2013. Comparative vitamins content of pulp, seed and rind of fresh and dried watermelon (Citrullus lanatus). International Journal of Science and Technology, 2(1): 99-103.

Kamel, B.S., Dawson, H., Kakuda, Y. 1985. Characteristics and composition of melon and grape seed oils and cakes. J Am Oil Chem Soc, 62: 881-883.

Karagöz, H. 2009. Türkiye ve Konya'da Hayvancılık Sektörü, Sektörün Sorunları ve Çözüm Önerileri. Konya Ticaret Odası, Konya.

Lambert, R.J.W. 2003. A model for the thermal inactivation of micro-organisms. Journal of Applied Microbiology, 95: 500-507.

Mann, A., Kiefer, M., Leuenberger, H. 2001. Thermal sterilization of heat-sensitive products using high-temperature short-time sterilization. Journal of Pharmaceutical Sciences, 90: 275-287.

Naz, A., Butt, M.S., Pasha, I., Nawaz, H. 2013. Antioxidant indices of watermelon juice and lycopene extract. Pakistan Journal of Nutrition, 12(3): 255-260.

Oberoi, D.P.S., Sogi, D.S. 2015. Drying kinetics, moisture diffusivity and lycopene retention of watermelon pomace in different dryers. J. Food Sci. Technol., 52(11): 7377-7384.

Sa'id, M.A. 2014. A Study in the variability of some nutrient contents of watermelon (Citrullus lanatus) before and after ripening consumed within Kano Metropolis, Nigeria. International Journal of Science and Research (IJSR), 3(5): 1365-1368.

Sabahelkhier, M.K., Ishag, K.E.A., Sabir Ali, A.K. 2011. Fatty acid profile, ash composition and oil characteristics of seeds of watermelon grown in Sudan. British Journal of Science, 1(2): 76-80.

TSE, 2019. TS 1132 Karpuz. (www.kanunum.com) (Erişim tarihi: 10.01.2019).

TUiK, 2019. Sebze Ürünleri Üretim Miktarları. 20012018.

(http://www.tuik.gov.tr/UstMenu.do?met od=temelist) (Erişim tarihi: 19.08.2019).

USDA, 2019. National Nutrient Database for Standard Reference Release 26 Full Report (All Nutrients) 09326, Watermelon, raw. "Nutrient values and weights are for edible portion", 
http://ndb.nal.usda.gov/ndb/foods/show/ 2438 (Erişim tarihi: 10.01.2019).

Van Soest, P.J., Robertson, J.B., Lewis, BA. 1991. Method for dietary fiber, neutral detergent fiber, and no starch polysaccharides in relation to animal nutrition. J. Dairy Sci., 74: 3583-3597.

Wani, A.A., Sogi, D.S., Grover Land Saxena, D.C. 2006. Effect of temperature, alkali concentration, mixing time and meal/solvent ratioon the extraction of watermelon seed proteins - a response surface approach. Biosyst. Eng., 94: 67-73.

Wani, A.A., Sogi, D.S., Singh, P., Wania, I.A., Shivhared, U.S. 2011. Characterization and functional properties of watermelon (Citrullus lanatus) seed proteins. Journal of the Science of Food and Agriculture, 91: 113-121.

Yaralı, E. 2019. Meyve ve Sebze Teknolojisi II. (https://sites.google.com) (Erişim tarihi: 18.01.2019).

Zanoni, B., Pagliarini, E., Giovanelli, G., Lavelli, V. 2003. Modelling the effects of thermal sterilization on the quality of tomato puree. Journal of Food Engineering, 56: 203-206.

Zohary, D., Hopf, M. 2019. Domestication of plants in the old world. 2000. 3rd Edn, New York: Oxford University Press, 316 p., (https://books.google.com.tr) (Erişim tarihi: 08.01.2019). 